\title{
Chapter 3 \\ Economic Aspects of Ukrainian Migration to EU Countries
}

\author{
Olga Kupets
}

\subsection{Introduction}

Two main phases can be identified in the development of economic migration research in Ukraine. In the 1990s to mid-2000s, descriptive or qualitative studies by demographers, sociologists and other researchers focused predominantly on emigration trends, and migration policy analysis was based on administrative statistics on residential migration, small-scale surveys of migrants or anecdotal evidence (e.g. Pirozhkov et al. 1997; 2003; Pribytkova 2002; 2003; Libanova and Pozniak 2002; Malynovska 2004; Pozniak 2007). Since 2008 more researchers have become involved in economic migration research and their focus has moved increasingly to the assessment of the costs and benefits of migration for Ukraine in the context of the migration-development nexus. The gathering of the first all-Ukrainian microlevel data on labour migration by the State Statistics Service in 2008 gave impetus to these studies, as did the significant improvement in the collection of macro data on personal remittances by the National Bank of Ukraine. The Labour Migration Survey, carried out in May-June 2008, employed the nationally representative combined sample of non-institutional households used in the monthly Labour Force Survey and in the quarterly Household Budget Survey, including in total 22,099 households and 48,054 individuals of working age (UCSR 2009; IDSS 2010). ${ }^{1}$ The next survey on labour migration issues using a nationally representative sample was

The original version of this chapter was revised. An erratum to this chapter can be found at DOI 10.1007/978-3-319-41776-9_14

${ }^{1}$ It was carried out by the State Statistics Service of Ukraine in cooperation with the Ukrainian Centre for Social Reforms, the Open Ukraine Foundation, IOM, and the World Bank.

O. Kupets $(\square)$

Kyiv School of Economics, Kyiv, Ukraine

e-mail: kupets@kse.org.ua 
conducted in 2012 as part of the EU-ILO project "Effective Governance of Labour Migration and its Skill Dimensions" (ILO 2013).

There is no single theoretical model that would bring together all aspects of economic migration research. For a systematic classification of numerous studies on Ukrainian labour migration, following Bauer et al. (2005), two main research areas can be identified:

1. Main reasons for migration, factors contributing to the decision to migrate for work and choice of destination country, with a focus on the consequences of the global economic crisis on migration flows between Ukraine and EU countries.

2. The economic impact of migration on Ukraine as a sending country.

The labour market performance of migrants in the destination countries and the effects of migration on destination countries are analyzed extensively in other chapters of this book (see Chap. 6 and Part II).

Analysis of the first theme, which is disproportionately over-represented in the research literature on migration of Ukrainian nationals, is an important prerequisite for a better understanding of the second theme, which is on the agenda of the current migration debate but remains under-researched in Ukraine. Ukrainian researchers tend to share the view that migration of Ukrainian nationals undermines regional and national economies by depriving them of valuable human resource capital, which is then exploited for the benefit of richer countries (for information about the Soviet legacy in contemporary migration research see Chap. 2). This perspective influences the research problems and approaches chosen and has implications for policy. In our review of economic migration research in Ukraine, we seek to consider both positive and negative economic effects of migration and remittances.

\subsection{The Economic Aspects of Labour Migration of Ukrainian Nationals to EU Countries}

\subsubsection{Reasons for Migration and Choice of Destination Country}

\section{Reasons for Ukrainian Migration}

Although there is an array of theories and conceptual frameworks of migration from the economic perspective, they have typically not been employed by Ukrainian researchers to provide explanations for the behaviour of Ukrainian migrant workers that has been observed. An extensive review of existing theories of labour migration developed by Western, Russian and Ukrainian scholars and the determinants of migration is provided in Maidanik (2010) and IDSS (2010). Maidanik (2010) also describes the patterns of labour migration of Ukrainian youth compared with the older population of working age, analyzes the impact of migration experience on young people (including the issues of the use of savings accumulated abroad for 
solving housing problems, human trafficking and inter-generational relations) and provides policy recommendations.

Alongside the use of simple statistical analysis or qualitative research to describe the main reasons for Ukrainian migration, Ukrainian researchers have been favouring "push-pull" theory, which has been heavily criticized by Western researchers (De Haas 2010). Quantitative studies also usually lack comparative analysis of the causes of migration among the different migrant groups (by age, gender, skill level, social status, overall economic situation at the time of departure, etc.), and this can often be attributed to samples being small and non-representative. For the same reasons, formal models of migration decision processes have rarely been used to test key hypotheses on the determinants of migration. Nevertheless, studies that predominantly describe the existing status quo without providing much explanation remain very valuable as they contribute to a better understanding of the mechanisms behind migration.

Recent studies of the reasons for Ukrainian labour migration based on various data sources show that the main driving force behind the decision to work abroad is usually labour migrants' desire to improve the living standards of their families; the major push factor for migration of Ukrainians is low wages and the main pull factor in the destination countries is anticipated higher earnings (ETF 2008; GfK 2008; UCSR 2009; Bogdan 2011; Kupets 2013). Qualitative research based on in-depth interviews with Ukrainian migrants working in European countries (e.g. IvankovaStetsiuk 2009; Kys 2010) and focus-group discussions with Ukrainians at home (Kupets et al. 2012) add that it is not only differentials in wage rates that matter for the decision to migrate abroad, but also the lack of stability of earnings in Ukraine due to widespread wage arrears and under-employment in the formal sector and even more acute problems in the informal sector. As a result, many Ukrainians have already chosen long-term labour migration to European countries or are considering the opportunity to secure stable earnings by migrating abroad. Interviews with local employers and population in Italy and Spain suggest that Ukrainians and migrants from other Eastern European countries are not using migration as an economic survival strategy but rather as a strategy to improve living conditions at home (Kys 2010, see also Chaps. 10 and 12).

Unemployment appears to be a less important reason for seeking work abroad than low wages in Ukraine and the possibility of earning quick money abroad (ETF 2008; GfK 2008; UCSR 2009; Bogdan 2011). This is not surprising because unemployment rates defined according to the ILO methodology are lower in Ukraine than in many destination countries, whereas average wages are significantly higher in all destination countries.

One study of the determinants of temporary work abroad among residents of a small town in Ukraine (Hormel and Southworth 2006) found that unemployment increases the odds of temporary labour migration. However, in-depth interviews conducted by the same authors reveal that the majority of the unemployed did not migrate. Estimates based on the Labour Migration Survey show that out of 1.3 million labour migrants in 2007-first half of 2008, only 37.2\% were not employed before moving abroad, whereas the rest had jobs in Ukraine but were dissatisfied 
with their wages (or income in the case of self-employment). This argument is further supported by recent analysis of migration intentions among unemployed school teachers in Ukraine (Kupets 2013); although four of the seven unemployed teachers interviewed were looking for employment abroad, they considered migration as second best to decent employment in Ukraine. Family reasons, lack of money to finance the move abroad and fear of the unknown (partly due to lack of information about the destination and the absence of social networks abroad) are among the most frequently mentioned factors against realization of migration intentions among the unemployed who were interviewed.

According to Bauer et al. (2005), some labour migrants may also aim to accumulate savings or develop skills while abroad in order to increase their economic opportunities in their places of origin. The evidence suggests (see GfK 2008; Kupets 2013) that most Ukrainian labour migrants who go abroad to earn quick money and reach a definite savings target (usually to improve housing conditions, pay for children's education or buy durable goods) typically assign a much lower priority to professional development and accumulation of skills abroad than to purely economic reasons. The issue of skills development among migrants, particularly among the highly skilled, did receive attention in the ILO-EU project "Effective Governance of Labour Migration and its Skill Dimensions", which was launched in 2011. Among other outcomes of this project, quantitative and qualitative analysis of international migration among teaching and research professionals shows that due to existing structural barriers, most migrant teachers from Ukrainian schools actually face a trade-off between skills development and low wages in Ukraine, and relatively high earnings but inadequate skills development abroad (Kupets 2013). Meanwhile, better opportunities for professional development and self-advancement abroad are taken very seriously by senior academics and researchers (both potential and current) in their migration decisions and choice of destination. Differences in motivation for migration based on education, skill level and social status need to be further investigated with a larger data set covering representatives of all professions.

\section{Ukrainian Labour Migrants' Choice of Destination Countries}

A further interesting research question posed mainly in the foreign-language literature is why Ukrainians seeking better economic opportunities go to Russia, Poland, Eastern or Southern European countries when, according to neoclassical economic theory, they would be expected to go wherever the expected net returns to migration are greatest, for example, to Austria, Germany or Scandinavian countries, which are relatively close to Ukraine and where income and employment opportunities are much better. After a careful analysis of the factors influencing migration decisions of Ukrainians moving from Komsomolsk to Russia and other former Soviet Union (FSU) countries, Hormel and Southworth (2006) conclude that people do not choose destinations exclusively on the basis of expected economic gain. They also use cultural capital (encompassing language, traditions and education) and social capital 
(ties to people and institutions that facilitate finding jobs and housing abroad) to diversify risk and maximize utility. Similar conclusions can be drawn from a study of Ukrainian teachers working abroad in low-skilled jobs, according to which the most popular reasons for choosing a particular destination country were "having relatives/friends abroad" and "better employment and/or income opportunities compared to other countries", followed by "knowledge of language of that country" and "geographical/cultural proximity of the country to Ukraine" (Kupets 2013). At the same time, quite important reasons also reported by over $20 \%$ of respondents were the relative ease of gaining visas, work/residence permits and irregular entry to the country of current destination.

A growing number of policy studies on Ukraine's path toward a visa-free regime with the $\mathrm{EU}^{2}$ suggest that visa issues are quite important for the choice of destination country, the economic performance of Ukrainians abroad and the consequences of the migration experience for both sending and receiving countries. In one sociological survey ${ }^{3}$ that only partially supports this statement, an absolute majority of Ukrainian respondents did not consider the visa regime with Europe to be a significant barrier to their emigration or labour migration, and reported their lack of financial means to be the major obstacle (Kipen and Avksentiev 2011). An interesting study by Weinar et al. (2012) that looks at the Schengen visa regime as a tool of labour migration policy and assesses the potential impact of liberalization of the visa regime on migratory movements between Ukraine and Moldova and the EU finds that the current Schengen visa regime has not been particularly successful in protecting labour markets in the destination countries from the flow of immigrant workers from Ukraine and Moldova. Szulecka (Chap. 4) discusses the impact of visa regimes on Ukrainian migrants in detail. Such a regime restricts the development prospects of the countries of origin by limiting circular migration, intellectual capital circulation and business exchanges. Fedyuk (Chap. 5) provides a critical analysis of the so-called social costs of Ukrainian labour migration.

\section{The Changing Economic Situation in Ukraine and Destination Countries and Its Impact on Migration Flows}

The third question with respect to economically driven migration of Ukrainians that deserves special attention is whether the improving labour market situation and living conditions in Ukraine before the global financial crisis that began in 2008 and the worsening situation in many European countries have caused migration flows to decrease and return migration flows to increase. This question remains

\footnotetext{
${ }^{2}$ See also publications of the NGO Europe Without Barriers at http://novisa.com.ua/en/publics

${ }^{3}$ The nationwide sociological survey "Migration potential of Ukraine in the context of acquiring a visa-free regime with the EU" was carried out in 2011 by the Donetsk Institute of Social Research and Policy Analysis with the support of Europe Without Barriers, a consortium of NGOs and think tanks set up by the International Renaissance Foundation. The results are presented in Kipen and Avksentiev (2011).
} 
under-researched because of the absence of comparative longitudinal data. ${ }^{4}$ The limited evidence available from administrative statistics in destination countries, surveys, focus-group discussions and in-depth interviews with migrants (e.g. IDSS 2010; Ivankova-Stetsiuk 2009; Stakanov 2011) has provided mixed results. Longterm migration flows from Ukraine seem to have decreased, particularly among highly skilled professionals providing knowledge-intensive services. ICT professionals benefit from better employment opportunities in Ukraine due to increasing outsourcing by foreign companies (Kupets 2013). On the other hand, an increasing number of students and young researchers are attracted by better opportunities for education and professional development abroad. For example, according to UNESCO's Institute for Statistics, ${ }^{5}$ the number of mobile students from Ukraine studying abroad at tertiary level increased from 25,826 (or $0.94 \%$ of total tertiary enrolment in Ukraine) in 2006 to 38,666 (or 1.62\%) in 2012.

Migration intensity among less skilled Ukrainians seeking work abroad has not decreased but rather has changed character: more and more Ukrainians prefer shortterm and circular migration, predominantly to neighbouring countries such as Russia and Poland whose labour markets were not as greatly affected by the crisis and are typically more open to Ukrainian workers. See, for example, the findings of two surveys of working-age individuals conducted in 2007 and 2011 in Ternopil Oblast, which is a migrant-exporting region in Ukraine (Shushpanov 2011), the analysis of labour force reallocation in Eastern Europe with two main attraction centres for migrants - Poland and Russia - (Kozynskii 2011) and the study of circular migration between Ukraine and Poland by Iglicka et al. (2011). See also Chap. 7 for a review of studies on Ukrainian migration to Poland.

As regards return migration, few of the Ukrainians who have been working in Southern or Western European countries for several years have chosen to return to Ukraine because of the fear of uncertainty at home and strong pull factors abroad, such as income differentials and a better quality of life (IDSS 2010; Stakanov 2011). Economic recession and decreasing labour demand have forced long-term labour migrants from Ukraine to consider self-employment or sectors that are less sensitive to business-cycle fluctuations; some of those who worked legally and lost their jobs because of the crisis moved onto welfare (Stakanov 2011; see also Chap. 8 on the Czech Republic, and Chap. 9 on Greece). For example, according to Marques and Góis (2007) since 2003 thousands of Ukrainians have left Portugal, seeking better income and employment opportunities in other European countries, such as Spain, France or the UK (see also Chap. 11). At the same time, such sectors as care, household or services have hardly been affected by the crisis, thus allowing Ukrainians, especially regularized women, to keep their jobs (UCSR 2009; IDSS 2010; Levchenko et al. 2010).

\footnotetext{
${ }^{4}$ The situation may change when the data from the 2012 wave of Labour Migration Survey becomes available to the wider research community.

${ }^{5}$ See http://data.uis.unesco.org (Accessed 4 Apr 2014).
} 


\subsubsection{The Economic Impact of Migration on Ukraine as a Sending Country}

Migration research in this area can be classified in many ways, one of which is according to the channels by which migration can affect the sending economy. The first part of the literature discusses the direct effects of emigration on the labour market, population stock and economic growth. The second concentrates on the effects of remittances, with a preliminary analysis of their trends and determinants (Leontiyeva and Tollarová 2011). The third deals with the analysis of return migration and its possible impacts. Finally, the fourth part of the literature, which is not described in detail below, is devoted to other aspects of migration, including the entrepreneurial potential of migrants' children (Maidanik 2011); the impact of migration on the education of the younger generation through incentive (or disincentive) effects and remittances (Vakhitova et al. 2013); projected skill needs in Ukraine and EU countries (Kolyshko and Panzica 2013); and the impact of international migration of teaching and research professionals on Ukraine's education system and economic development through various channels, including the intellectual diaspora (Kupets 2013). There are also synthesis studies such as Malynovska (2011) or IDSS (2010) that analyze various possible effects of labour migration from Ukraine. A comprehensive study of the costs and benefits of labour mobility between the EU and the Eastern Partnership countries (Armenia, Azerbaijan, Belarus, Georgia, the Republic of Moldova and Ukraine), with forecasts of future migration flows and implications for sending and destination areas, is the main outcome of an EU-funded project. ${ }^{6}$

\section{Direct Impact of Migration on the Ukrainian Economy and Population}

In the group of studies on the economic and demographic effects of Ukrainian labour migration, the research of O. Pozniak (2007, 2012), deserves special mention. In his research paper, prepared as part of the CARIM-East project in 2012, he estimated that adjusted numbers for de jure population at the beginning of 2008, taking into account labour migration (on estimates of Ukrainian labour migrants, see Chap. 1), would be about 583,000 (or 1.3\%) lower than the official statistics of the State Statistics Service of Ukraine showed (45,609,000 vs. 46,192,000 people). Besides, the share of people aged 65 and over in this "adjusted" de jure population would be slightly larger (16.5\% vs. $16.3 \%)$. These estimates suggest that labour migration negatively affects the population stock and its age structure. The effects of labour migration on other demographic indicators such as birth, fertility,

\footnotetext{
${ }^{6}$ See http://www.enpi-info.eu/main.php?id=18637\&id_type=4\&lang_id=450. The project was carried out by a consortium composed of CASE (Warsaw), IZA (Bonn), CEU (Budapest), the London School of Economics Enterprise and local partners in the EaP countries, including Kyiv School of Economics in Ukraine, in 2011-13. The outcomes of the project are available at http:// www.case-research.eu/en/migration_ENPI (Accessed 1 July 2013).
} 
marriage, divorce and mortality rates are not estimated because of the lack of reliable statistics.

At the same time, Pozniak (2012) found empirical support for a hypothesis of the positive effect of migration on the Ukrainian labour market: the unemployment rate in the first half of 2008 would be almost twice as high (12.2\% vs. 6.2\%) had Ukrainians not migrated abroad or had all labour migrants returned at once. Although labour migration undoubtedly provided temporary relief from unemployment in Ukraine, particularly in the late 1990s-early 2000s, assessment of the quantitative effect, based on the assumption that all labour migrants would be otherwise unemployed in Ukraine, is not conclusive.

The other side of the coin with respect to the impact of international migration on labour supply is that Ukraine is expected to face severe labour shortages very soon because the working-age population is shrinking due to natural population decrease and emigration of working-age individuals, return migration of Ukrainians (many of whom have already settled abroad) seems to be very small and immigration alone is insufficient to compensate for population losses. There are already signs of shortages of health workers, teachers, construction workers, welders and drivers in some migrant sending regions, and most worryingly, these are often the most active and entrepreneurial people (Malynovska 2011). According to projections made by the Institute of Demography and Social Studies, the first signs of labour shortage in Ukraine will show in 7 years and in 10-12 years' time this problem will be more evident. It is estimated that between 2012 and 2061, a total of 7.9 million additional workers will be needed (Pozniak 2012).

Some researchers also stress that there may be skill shortages even in the case of large flows of return migrants due to widespread skill downgrading while working abroad and the low economic activity of those who intend to go abroad again (Bogdan 2011; Kupets 2011). Besides, there is anecdotal evidence of the moral hazard problem induced by migration and remittances, which is reflected in decreasing economic activity among the members of households with at least one labour migrant, particularly among the young, though this fact is not statistically proven (IDSS 2010).

Another frequently mentioned concern in the Ukrainian literature and mass media is the "brain drain" or large-scale emigration of highly skilled professionals including scientists, engineers, doctors and IT specialists (Kupets 2013). One important implication is that investment in education in Ukraine may not lead to faster innovation-led economic growth because a large number of its highly educated people leave the country. However, some researchers focusing on the subject argue that the problem of emigration of highly skilled professionals is often exaggerated and mythicized because available statistical information is scarce and inconclusive (Parkhomenko 2006; Genov 2007). Currently, nobody in Ukraine can say with certainty how many highly skilled professionals leave the country each year, how these numbers change over time and how they compare to the total stock of professionals remaining. As regards the outflow of Ukrainian scientists, analysis of administrative statistics reported by the State Statistics Service of Ukraine reveals a decreasing level of emigration for permanent residence abroad (e.g. from $184 \mathrm{PhD}$ 
students in 1996 to 51 in 2012, and from 59 individuals with a PhD degree in 1995 to 5 in 2012) and an increase in short-term academic trips and international scientific collaboration (Kupets 2013; see also Chap. 1). Furthermore, intellectual migration is increasingly driven more by opportunity than by needs as it was in the 1990s.

\section{Trends, Determinants and Economic Effects of Remittances}

Earlier studies on remittances focused on estimates of their size or descriptions of trends and macro- or micro-level characteristics (see, e.g., Haidutskii (2007a, 2007b) for a macro-level descriptive analysis; UCSR (2009) and IDSS (2010) for description of remittances at the household level). Libanova (2011) contributed to the literature by analyzing the impact of private remittances on poverty and income inequality in Ukraine. As expected, remittances are found to have positive effects on the material well-being of recipient households. At macro level they played an important role in reducing the incidence and severity of poverty. But they also increased income inequality, being the fourth important determinant after wages, pensions and entrepreneurial income. Several recent studies in the Czech Republic (Leontiyeva and Tollarová 2011; Strielkowski 2011; Strielkowski et al. 2012) show that there is no significant correlation between the amounts remitted and the income level of the receiving household, and that receiving remittances lowers the odds of spending household income primarily on current consumption but increases the odds of spending it on education and housing (Strielkowski et al. 2012; see also Chap. 8). The empirical estimation of the education demand on the household by Vakhitova et al. (2013) reveals that, after controlling for other factors, average expenditures on education among remittance-receiving households are larger but marginal propensity to invest in education is higher among non-receiving households. This finding implies that remittance-receiving households tend to spend less from each additional unit of income and therefore an increase in remittances is unlikely to substantially contribute to the demand for education in Ukraine.

An attempt to provide a synthesis of existing and emerging scholarly knowledge on the effects of remittances in Ukraine and other CIS countries was recently supported by the CARIM-East project (Kupets 2012). The author reviewed the descriptive and empirical literature, provided analysis where possible, offered policy implications and identified gaps in the literature. Analysis of official statistics on remittance flows in Ukraine revealed that remittances in US\$ rose steadily until 2008 but as the domestic economy and the economies of Russia and the EU - the major regional sources for remittances into Ukraine - went into crisis in 2009, inflows slightly decreased. Nevertheless, the decline in remittances and their volatility was smaller than those of foreign direct investment (Fig. 3.1). At the same time, the amount of remittance inflows measured in local currency increased steadily, acting as a hedge against negative shocks in the home country for recipient households. Due to the rapid recovery, almost to pre-crisis level, of remittances from Russia in 2010, total inflows to Ukraine also increased. This demonstrates the heavy dependence of the Ukrainian economy on that of Russia, not only in terms of the frequently 


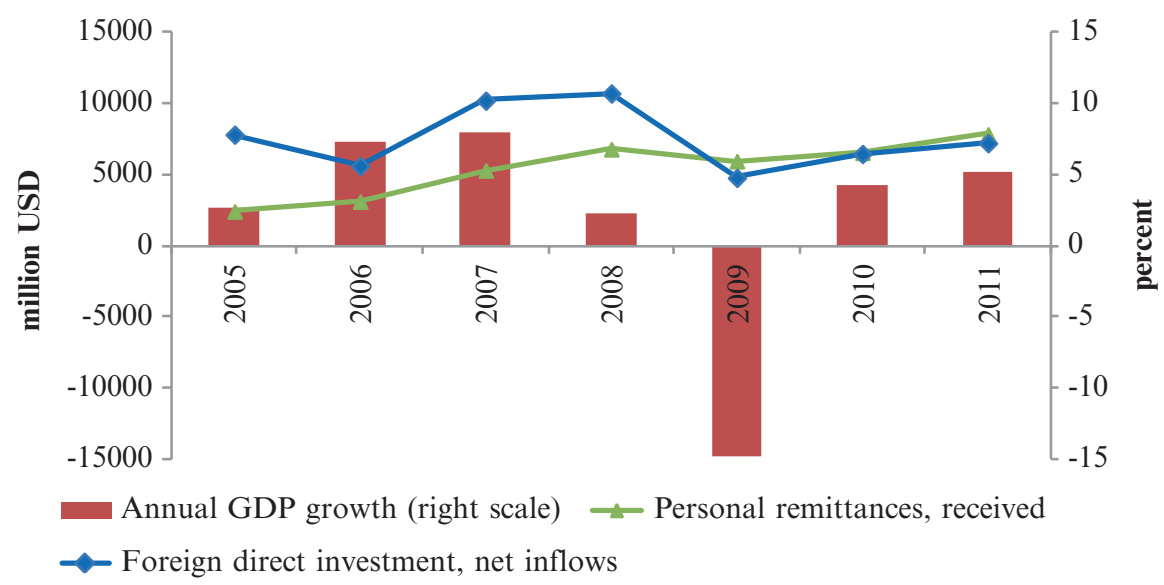

Fig. 3.1 Remittances and foreign direct investment to Ukraine, 2005-2011 (Source: World Development Indicators on-line data set (Accessed July 2013))

mentioned international trade and financial channels, but also in terms of remittances. The main conclusion of the study is that the development effects of remittances in Ukraine are often contradictory and contingent upon many factors, and that there is still much to be done to gain a better understanding of the factors influencing remittance behaviour of migrants and spending behaviour of remittancereceiving households.

\section{Return Migration and its Developmental Potential}

Research studies dealing with the effects of return migration on the Ukrainian economy and demographic profile can be divided into two types. The first is based on qualitative research - in-depth interviews and focus-group discussions with migrants and experts - and provides a deep insight into migrants' experiences, their return intentions and problems encountered (Ivankova-Stetsiuk 2009; Kys 2010; Kubal 2012). Kys (2010) identified two main groups of returners: (i) the "disappointed", who returned because of nostalgia for home and family, unwillingness to live with the humiliating status of a foreigner and a slave, or the impossibility of earning the desired amount; and (ii) the "missionaries" returning home after the successful completion of their mission, such as a savings goal, end of employment contract or an attractive job offer in Ukraine.

Studies of the second type are mainly quantitative, and complement or support the findings of qualitative research. For example, the typology of return migrants offered by Kupets (2011) is very similar to the one mentioned above but there is also information on the proportion of each group of return migrants: (i) "retirement return", 4.8\%; (ii) "innovation return", 2.5\%; (iii) "conservatism return" ("missionaries" in the Kys typology), 37.5\%; and (iv) "failure return" (Kys' "disappointed" 
plus deportees), $55.2 \%$. So, very few returnees were innovative agents of change who invested in their own business and created jobs, probably due to existing entry barriers, the high administrative costs of doing business, inadequate contract enforcement and other barriers to business in Ukraine. This study, which is based on 2008 Labour Migration Survey data, examines observable characteristics of return labour migrants, identifies the factors determining return decisions and analyzes the performance of return labour migrants in Ukraine compared to non-migrants, applying the multinomial probit model and correcting for sample selection bias into return migration. The study concludes that so far there is no strong evidence of "brain gain" from return labour migration in Ukraine because of the skill waste experienced in the host countries, the disadvantages of return migrant status and the low probability of finding suitable work in Ukraine because of high reservation wage $^{7}$ among (former) migrants.

A quantitative study by Markov (2006) based on a survey of Ukrainian migrants in Italy in 2002-2003 looks at the plans of migrants willing to return in terms of their entrepreneurial characteristics and potential economic activity in Ukraine. Two other quantitative studies of return migration (ETF 2008; Bogdan 2011) also provide policy recommendations on how to integrate returning migrants into the local community and labour market, and how to harness the contribution of return labour migration for Ukraine's development taking into account the high propensity of former migrants to set up entrepreneurial activity and create jobs. In particular, the latter study emphasizes the need for a long overdue national policy on reintegration of return migrants in Ukraine, the highlights of which should cover (a) coordination with EU states' programmes on assisted voluntary return for Ukrainian nationals; (b) comprehensive and widely distributed information about the points of the reintegration policies supported by the Ukrainian state; (c) close cooperation with regional and local authorities on programmes providing temporary housing and support with employment for the return migrants;and (d) availability of microcredit for entrepreneurial projects by return migrants (Bogdan 2011).

The Institute of Demography and Social Studies macro-level studies (IDSS 2010; Pozniak 2012) estimated that if all migrants working abroad as own-account workers and employers (16\% and 4.7\% of all labour migrants in 2007-2008 respectively) had returned to Ukraine and retained the same employment status, the unemployment rate would have decreased from $6.2 \%$ to $5.6 \%$ or $5.4 \%$ depending on the number of employees hired by each entrepreneur among returnees (three or five employees on average). This could also have increased tax revenues by $€ 18$ million from entrepreneurs themselves plus between $€ 24$ million and $€ 40$ million as personal income tax from their employees. Between $€ 43$ million and $€ 72$ million could also have been saved from the State Unemployment Insurance Fund if these entrepreneurs hired the former registered unemployed (Pozniak 2012). However, these effects are mere hypotheses because as yet conditions in Ukraine are not propitious

\footnotetext{
${ }^{7} \mathrm{~A}$ reservation wage is the lowest wage rate at which a worker would be willing to accept a particular type of job.
} 
for small businesses to make productive investments and establish supply-chain relations with foreign colleagues.

\subsection{Conclusions}

The above overview of the literature dealing with economic aspects of Ukrainian labour migration to the EU and other countries gave information on the main trends and findings of the research. However, it is by no means exhaustive, given that there are plenty of short and fragmentary studies that simply duplicate previous work, and the long monographs of several authors lack consistency and clear focus.

Significant progress has been made in qualitative research on labour migration issues. Below we identify several topics that deserve further research attention, given their academic and policy importance:

- Reasons for migration depend on education and skills (not only level but also field), social status of migrants and other individual and family characteristics.

- The determinants of various types of migration (by purpose - education; employment; family reunification, etc.; skill level of migrants; duration and frequency) and selectivity issues.

- Labour market behaviour of household members receiving remittances compared to other households.

- The degree of substitutability between international and internal labour migration.

- The relationship between the ageing of the Ukrainian population, labour migration and labour market situation, given that older workers are less mobile and so are less likely to respond to economic shocks by migrating. Besides, ageing population increases demand for care services that may raise the issue of "care drain" because of mass migration of Ukrainian women caring for the elderly abroad but not for their parents in Ukraine.

- The impact of growing youth unemployment in European countries on migration motives of young Ukrainians seeking a better life.

- The impact of the global economic crisis on migration behaviour, the magnitude, type and composition of migration flows, with a subsequent analysis of the effects of these changes on pertinent economies. It would also be good to examine carefully the phenomenon of "temporary return" (found by Hosnedlová (2012) in Spain among unemployed Ukrainians who have a residence/work permit and return to Ukraine for a time) and its consequences for both Ukraine and countries where many Ukrainians have become naturalized or at least regularized but have subsequently lost their jobs because of the economic crisis. 


\section{References}

Bauer, T. K., Haisken-DeNew, J. P., \& Schmidt, C. M. (2005). Chapter 7. International labour migration, economic growth and labour markets: The current state of affairs. In M. Macura, A. L. MacDonald, \& W. Haug (Eds.), The New demographic regime: Population challenges and policy responses (pp. 111-135). New York/Geneva: United Nations.

Bogdan, T. (2011). Labor migrants' problems - Acute policy challenge for Ukraine. Study carried out in the framework of local government initiative fellowship 2010/2011 within the Open Society Foundation's (OSF) project "Developing Economic Reintegration Initiatives for Ukrainian Labor Migrants". Available at: http://mirpal.org/files/files/Article_2\%20\%D0\%98\% D0\%BD\%D1\%84\%D0\%BE\%D1\%80\%D0\%BC\%D0\%B0\%D1\%86\%D0\%B8\%D1\%8F.pdf

De Haas, H. (2010). Migration and development: A theoretical perspective. International Migration Review, 44(1), 227-264.

European Training Foundation (ETF). (2008).The contribution of human resources development to migration policy in Ukraine, Turin: ETF, working document. Available at: http://etf.europa.eu/ web.nsf/pages/The_contribution_of_human_resources_development_to_migration_policy_in_ Ukraine_EN

Genov, N. (2007). Brain-Drain from eastern Europe? What we know about and What Not?, paper presented at the second IZA workshop on EU enlargement and the labor markets in Bonn, 7-8 September 2007. Available at: http://www.iza.org/conference_files/EUEnlarge2007/genov_ n3662.pdf

GfK. (2008). Human trafficking survey: Belarus, Bulgaria Moldova, Romania, and Ukraine, prepared by the GfK Ukraine for the International Organization for Migration, Kyiv Office.

Haidutskii, A. (2007a). Masshtaby potokiv migratsiynogo kapitalu v Ukrayinu [Magnitude of migration capital flows to Ukraine]. Herald of the National Bank of Ukraine, 10, 11-15.

Haidutskii, A. (2007b). Migratsiyniy kapital v Ukrayini [Migration capital in Ukraine]. Finances of Ukraine, 5, 24-37.

Hormel, L. \& Southworth, C. (2006, Jun). Eastward bound: A case study of Post-Soviet labour migration from a rural Ukrainian town, Europe-Asia Studies, 58(4), 603-623.

Hosnedlová, R. (2012). Decidiendo el futuro: la cuestión de retorno y redes personales de los inmigrantes ucranianos en la Comunidad de Madrid. Doctoral thesis, Universidad Complutense de Madrid, España.

Iglicka, K., Gmaj, K., \& Borodzicz-Smoliński, W. (2011). Circular migration patterns. Migration between Ukraine and Poland. METOIKOS Project, Robert Schuman Centre for Advanced Studies, San Domenico di Fiesole (FI): European University Institute.

Institute of Demography and Social Studies of NASU (IDSS). (2010). Naselennya Ukrayiny. Trudova emigratsiya z Ukrayiny [Population of Ukraine. Labour emigration from Ukraine]. Kyiv: IDSS.

International Labour Organization (ILO). (2013). Report on the methodology, organization and results of a modular sample survey on labour migration. Kyiv/Budapest: ILO/ILO Decent Work Technical Support Team and Country Office for Central and Eastern Europe.

Ivankova-Stetsiuk, O. (2009). Ukrayinska trudova migratsiya v yakisnomu vymiri: za materialami glybynnyh interv'yu ta fokus-grup [Ukrainian labour migration in the qualitative dimension: Based on the materials of In-depth interviews and focus groups]. In I. Markov (Ed.), Na rozdorizhzhi. Analitychni materialy kompleksnogo doslidzhennya protsesiv ukrayinskoyi trudovoyi migratsiyi (krayini Evropeyskogo Soyuzu i Rosiyska Federatsiya) [At the crossroads: Analytical materials of the complex research on Ukrainian labour migration (Countries of the European Union and Russian Federation)] (pp. 123-190). Lviv: Caritas Foundation.

Kipen, V., \& Avksentiev, M. (2011). Mihratsijnyj capital Ukrajiny v kontekstivizovohorezhymu z ES: analitychnyjzvit. [Migration potential of Ukraine in the context of acquiring a visa-free regime with the EU: Analitycal report], Institute of Social Research and Political Analysis, Donetsk: Institute of Social Research and Political Analysis. 
Kolyshko, R., \& Panzica, F. (2013). Analysis of vacancies and skills needs in Moldova and Ukraine and EU countries of destination. Report prepared for the ILO-EU project "Effective Governance of Labour Migration and its Skill Dimensions".

Kozynskii, S. (2011). Migratsiya robochoyi syly ta konkurentospromozhnist natsionalnyh ekonomik u shidnoevropeyskomu regioni: vyklyky dlya Ukrayiny [Migration of the labour force and competitiveness of the national economies in the eastern European region: Challenges for Ukraine]. In O. Malynovska (Ed.), Sotsialno-ekonomichni ta etnokulturni naslidki migratsiyi dlya Ukrauiny: zb. materialiv nauk.-prakt. konferentsiyi [Socio-Economic, ethnic and cultural consequences of migration for Ukraine: Conference proceedings] (pp. 62-71). Kyiv: National Institute for Strategic Studies.

Kubal, A. (2012). Facts and fabrications. Experiences of law and legality among return migrants in Ukraine. Working Paper No. 59/2012. Oxford: International Migration Institute. Available at:

http://www.imi.ox.ac.uk/publications/imi-working-papers/ wp-59-2012-facts-and-fabrications-experiences-of-law-and-legality-among-return-migrantsin-ukraine

Kupets, O. (2011). Brain gain or brain waste? The performance of return labor migrants in the Ukrainian labor market. Working paper No 11/06E. Kiev: EERC. Available at: http://www. eerc.ru/default/download/creater/working_papers/file/e06582977985dd1176007ac43d796aaca23edca8.pdf

Kupets, O. (2012). The development and the side effects of remittances in the CIS countries: The case of Ukraine.CARIM-East Research Report 2012/02. Robert Schuman Centre for Advanced Studies, San Domenico di Fiesole (FI): European University Institute. Available at: http:// www.carim-east.eu/media/CARIM-East-2012-02.pdf

Kupets, O. (2013). International mobility of Ukrainian teaching and research professionals. Kyiv/ Budapest: ILO/ILO Decent Work Technical Support Team and Country Office for Central and Eastern Europe.

Kupets, O., Babenko S., \& Vakhitov V. (2012). Ukraine Case Study: Jobs and Demographic Change. A background paper prepared for the World Development Report 2013. Available at: h t t p : / / s iteresources.worldbank.org/EX T N W R 2013 / Re sour ces/8258024-1320950747192/8260293-1320956712276/8261091-1348683883703/ WDR2013_bp_Jobs_And_Demographic_Change.pdf

Kys, R. (Ed.). (2010). Trudova migratsiya yak instrument internatsionalizatsiyi. Zbirka materialiv kompleksnogo doslidzhennya trudovoyi migratsiyi i rynkiv pratsi (Ispaniya, Italiya, Moldova, Ukrayina, Rosiyska Federatsiya) [Labour migration as a tool of internationalization. A collection of materials o the complex research on labour migration and labour markets (Spain, Italy, Moldova, Ukraine, Russian Federation)]. Lviv: Drukarski kunshty.

Leontiyeva, Y., \& Tollarová, B. (2011). Results from a survey of foreigners' incomes, expenditures and remittances. Main findings concerning remittances. Prague: Sociologický ústav AV ČR. Available at: http://www.soc.cas.cz/articles/cz/5/6127/ Leontiyeva-Y.-B.-Tollarova-2011.-8222-Resultsfrom-a-Survey-of-Foreigners-8217-IncomesExpenditures-and-Remittances.-Main-Findings-Concerning-Remittances-8220-.-PrahaSociologicky-ustav-AV-CR-v.v.i.html

Levchenko, K., Malinovskaya, E., Shvab, I., \& Trofimenko, O. (2010). Ukrainskaya Gretsiya: prychyny, problemy, perspektivy (po rezultatam oprosa trudovyh migrantov) [Ukrainian Greece: Reasons, problems, prospects (according to labour migrants' interviews)]. Institute of Sociology NASU and International Women's Rights Centre La Strada Ukraine, Kyiv: Agency Ukraine.

Libanova, E. (2011). Migratsiyni transferty, bidnist ta nerivnist v Ukrayini [Remittances, poverty and inequality in Ukraine].In O. Malynovska (Ed.), Sotsialno-ekonomichni ta etnokulturni naslidki migratsiyi dlya Ukrauiny: zb. materialiv nauk.-prakt. konferentsiyi [Socio-Economic, ethnic and cultural consequences of migration for Ukraine: Conference proceedings] (pp. 15-25). Kyiv: National Institute for Strategic Studies,

Libanova, E., \& Pozniak, O. (Eds). (2002). Zovnishni trudovi migratsiyi naselennya Ukrayiny [External labour migration of the Ukrainian population]. Kyiv: RVPS. 
Maidanik, I. (2010). Ukrayinska molod na rynkah pratsi zarubIzhnyh krayin [Ukrainian youth on the foreign labour markets]. Kyiv: Institute of Demography and Social Studies of NASU.

Maidanik, I. (2011). Pidpryemnytskiy potentsial ditey trudovyh migrantiv v Ukrayini [Entrepreneurial potential of labour migrants' children in Ukraine].In O. Malynovska (Ed.), Sotsialno-ekonomichni ta etnokulturni naslidki migratsiyi dlya Ukrauiny: zb. materialiv nauk.prakt. konferentsiyi [Socio-Economic, ethnic and cultural consequences of migration for Ukraine: conference proceedings] (pp. 131-142). Kyiv: National Institute for Strategic Studies.

Malynovska, O. (2004). Ukrayina, Evropa, migratsiya: migratsiyi naselennya Ukrayiny v umovah rozshyrennya ES [Ukraine, Europe, Migration: Migration of the Ukrainian population under conditions of the EU enlargement]. Kyiv: Blank-Press.

Malynovska, O. (2011). Trudova migratsiya: sotsialni naslidki ta shlyahy reaguvannya [Labour migration: Social consequences and political response]. Kyiv: National Institute for Strategic Studies. Available at: http://www.niss.gov.ua/articles/607/

Markov, I. (2006). Deyaki rysy suchasnoyi ukrayinskoyi trudovoyi migratsiyi [Some peculiarities of the present-day Ukrainian labour migration]. Independent Culturological Magazine "Ji", (pp. 65-72). Available at: http://www.ji-magazine.lviv.ua/ji-junior/loginov/markov.htm

Marques, J. C., \& Góis, P. (2007). Ukrainian migration to Portugal. From non-existence to the top three immigrant groups. migrationonline.cz. Available at: http://aa.ecn.cz/img_upload/3bfc4dd c48d13ae0415c78ceae108bf5/JCMarquesPGois_UkraniansinPortugal.pdf

Parkhomenko, N. (2006). Brain drain from Ukraine: Current situation and future challenges. Centre for Peace, Conversion and Foreign Policy of Ukraine (CPCFPU), Policy Paper 3/2006. Available at: http://cpcfpu.ru/en/projects/foreignpolicy/papers/306/

Pirozhkov, S., Malynovska, O., \& Marchenko, N. (1997). Zovnishnya migratsiya v Ukrayini: prychyny, naslidki, strategiyi [External Ukrainian migration: Causes, consequences and strategies]. UNECE, National Institute of Strategic Studies, Kyiv: Academpress.

Pirozhkov, S., Malinovskaya, E., \& Homra, A. (2003). Vneshnie trudovyie migratsii v Ukraine: sotsialno-ekonomicheskiy aspekty [Foreign labour migration in Ukraine: Socio-economic aspects]. Kiev: NIPMB.

Pozniak, O. (Ed.). (2007). Migratsiyni protsesy v Ukrayini: suchasniy stan i perspektyvy [Migration trends in Ukraine: Current situation and future prospects]. Uman: SPD Sochynskiy.

Pozniak, O. (2012). External labour migration in Ukraine as a factor in socio-demographic and economic development. CARIM-East RR 2012/14, Robert Schuman Centre for Advanced Studies, San Domenico di Fiesole (FI): European University Institute. Available at: http:// www.carim-east.eu/media/CARIM-East-2012-RR-14.pdf

Pribytkova, I. (2002). Trudovi migranty u sotsialniyy ierarhiyi ukrayinskogo suspilstva: statusni pozitsiyi, tsinnosti, zhittevi strategiyi, styl $i$ sposib zhyttya [Labor migrants in the hierarchy of the Ukrainian society: status, values, life strategies and life style]. Part I, Sociology: theory, methods and marketing, 4, 156-167.

Pribytkova, I. (2003). Trudovi migranty u sotsialniyy ierarhiyi ukrayinskogo suspilstva: statusni pozitsiyi, tsinnosti, zhittevi strategiyi, styl $i$ sposib zhyttya [Labor migrants in the hierarchy of the Ukrainian society: status, values, life strategies and life style]. Part II, Sociology: theory, methods and marketing, 1, 109-124.

Shushpanov, P. (2011). Novitni tendentsiyi zovnishnoyi trudovoyi migratsiy naselennya Ternopilskoyi oblasti [New trends in International labour migration of population in Ternopil Oblast]. In O. Malynovska (Ed.), Sotsialno-ekonomichni ta etnokulturni naslidki migratsiyi dlya Ukrauiny: zb. materialiv nauk.-prakt. konferentsiyi [Socio-Economic, ethnic and cultural consequences of migration for Ukraine: conference proceedings] (pp. 150-154). Kyiv: National Institute for Strategic Studies.

Stakanov, R. (2011). Trudova emigratsiya do ta pislya svitovoyi kryzy: perspektyvy ta naslidky dlya ekonomiky Ukrayiny [Labour emigration before and after the global crisis: Prospects and consequences for the Ukrainian economy]. In O. Malynovska (Ed.), Sotsialno-ekonomichni ta etnokulturni naslidki migratsiyi dlya Ukrauiny: zb. materialiv nauk.-prakt. konferentsiyi [Socio-Economic, ethnic and cultural consequences of migration for Ukraine: conference proceedings] (pp. 72-82). Kyiv: National Institute for Strategic Studies. 
Strielkowski, W. (2011). Tovarno-denezhnyie perevodyi iz Chehii v Ukrainu: issledovanie v ramkah proekta po izucheniyu ukrainskoy migratsii [Remittances from Czechia to Ukraine: Study within the project on Ukrainian migration research]. In O. Malynovska (Ed.), Sotsialnoekonomichni ta etnokulturni naslidki migratsiyi dlya Ukrauiny: zb. materialiv nauk.-prakt. konferentsiyi [Socio-Economic, ethnic and cultural consequences of migration for Ukraine: conference proceedings] (pp. 115-121). Kyiv: National Institute for Strategic Studies.

Strielkowski, W., Glazar O., \& Weyskrabová B. (2012). Migration and remittances in the CEECs: A case study of Ukrainian labour migrants in the Czech Republic. Working Paper No. 19/2012, Prague: Institute of Economic Studies, Charles University. Available at: http://ies.fsv.cuni.cz/ default/file/download/id/20821

Ukrainian Centre for Social Reforms (UCSR), State Statistics Committee of Ukraine. (2009). Zovnishnya trudova migratsiya naselennya Ukrayiny [International labour migration of the Ukrainian population]. Kyiv: UCSR.

Vakhitova, G., Coupe, T., \& Sologoub, I. (2013). The relations between education and migration in Ukraine. Kyiv/Budapest: ILO/ILO Decent Work Technical Support Team and Country Office for Central and Eastern Europe.

Weinar, A., Korneev, O., Makaryan, S., \& Mananashvili, S. (2012).Consequences of Schengen Visa liberalisation for the citizens of Ukraine and the republic of Moldova. MPC Research Report 2012/1, Robert Schuman Centre for Advanced Studies, San Domenico di Fiesole (FI): European University Institute.

Open Access This chapter is distributed under the terms of the Creative Commons AttributionNoncommercial 2.5 License (http://creativecommons.org/licenses/by-nc/2.5/) which permits any noncommercial use, distribution, and reproduction in any medium, provided the original author(s) and source are credited.

The images or other third party material in this chapter are included in the work's Creative Commons license, unless indicated otherwise in the credit line; if such material is not included in the work's Creative Commons license and the respective action is not permitted by statutory regulation, users will need to obtain permission from the license holder to duplicate, adapt or reproduce the material. 